\title{
TINGKAT PENDAPATAN PENGUSAHA KAYU GERGAJIAN BERDASARKAN MARGIN KEUNTUNGAN DAN ALUR PEMASARAN KAYU LOKAL DI DISTRIK MANOKWARI UTARA
}

\section{(Earning Rate of Wooden Processing Sellers Based on Profit Margin and Selling Flow of Local Wooden Process in Manokwari Utara Sub-District)}

\author{
Febriyanti Dedan Paririe ${ }^{1}$ Jonni Marwa ${ }^{1 凶}$ dan Novita Panambe ${ }^{1}$ \\ Jurusan Kehutanan, Fakultas Kehutanan Universitas Papua Manokwari, Papua Barat, \\ 98314. Tlp/Fax: +62986211065. \\ ${ }^{\square}$ Penulis Korespondensi: Email: jonnimarwa@gmail.com \\ Diterima: 02 Okt 2019| Disetujui: 27 Okt 2019
}

\begin{abstract}
Abstrak
Tujuan penelitian ini adalah untuk mengetahui pendapatan di tingkat pengusaha kayu (pemilik hak ulayat, penampung kayu, dan pengusaha kayu), menilai margin keuntungan di masing-masing pengusaha kayu dan mendeskripsikan alur dan mekanisme/sistem penebangan dan pemanfaatan kayu. Penelitian ini dirancang menggunakan metode deskriptif dengan teknik survei lapangan dan objek dalam penelitian ini adalah pengusaha kayu gergajian yang mengolah hasil hutan di Distrik Manokwari Utara. Data yang diperoleh dianalisis secara deskriptif dan ditampilkan dalan tabulasi. Hasil penelitian menunjukkan bahwa pendapatan hak ulayat sekaligus pengusaha kayu sebesar Rp. 29.400.000/tahun, pemilik hak ulayat sekaligus penampung kayu Rp. 13.100.000/tahun dan pengusaha kayu Rp. 28.000.000/tahun. Margin keuntungan pemilik hak ulayat sekaligus pemilik stand kayu adalah $56,112 \%$, pemilik hak ulayat yang juga penampung kayu $35,85 \%$ dan pegusaha kayu 30,82\%. Alur perdagangan kayu yang berasal dari Distrik Manokwari Utara dijual ke pasar lokal di Distrik Manokwari Utara dan dalam kota Manokwari dengan margin keuntungan tertinggi adalah saluran pemasaran dari stand kayu ke konsumen akhir di kota Manokwari dan sekitarnya.
\end{abstract}

Kata kunci: tingkat pendapatan, kayu gergajian, alur pemasaran, margin keuntungan, hak ulayat

\begin{abstract}
This study aims at revealing income rates of wood small concessioners (customary right holder, temporarily wooden damping employee, wooden entrepreneur), assessing profit margins at each wooden entrepreneur as well as describing a mechanism flow of wood sortiment after cutting down. The study designed using a descriptive method by way of field observation technique for the main object which is wooden entrepreneurs that managed multiple forest products in the area of North Manokwari sub-district. Data obtained then analyzed descriptively and the information presented in tabulated forms. The result noticed the income of customary right holder as well as wooden entrepreneur earned was IDR 29,400,000/year, while for customary right holder as well as temporarily wooden damping employee earned IDR 13,100,000/year and wooden entrepreneur was IDR 28/year. The profit margin of customary right holder as well as wooden entrepreneur was $56.112 \%$,
\end{abstract}


while for the customary right holder as well as temporarily wooden damping employee was $35.85 \%$ and wooden entrepreneur was about 30.82\%. Wooden trade flow that initiated from North Manokwari sub-district was then sold to the closed surrounding areas and market in the city of Manokwari by the highest profit margin was the flow from wood processing sellers to the ending consumers in the surrounding of Manokwari area.

Keywords: earning rate, wooden sawn, trade flow, profit margin, customary right

\section{PENDAHULUAN}

Papua merupakan bagian dari wilayah Negara Kesatuan Republik Indonesia yang terletak di bagian paling timur gugusan kepulauan nusantara. Papua memiliki potensi kekayaan alam yang berlimpah yang penuh dengan potensi hasil hutan kayu dan bukan kayu. Sebagian besar wilayah Papua Barat merupakan kawasan hutan dengan total kawasan hutan seluas 31 juta hektar yang terbagi atas kawasan konservasi $(44,8 \%)$ dan kawasan hutan produksi $(52,6 \%)$ sedangkan $(2,6 \%)$ adalah areal penggunaa lainya (APL) (The World Bank 2008).

Hutan mempunyai peranan yang cukup penting dalam memenuhi kebutuhan hidup manusia. Masyarakat yang tinggal di dalam maupun di sekitar hutan memanfaatkan hutan sebagai sumber penghasilan bahan makanan/minuman, sumber obat-abatan, bahan senjata/perkakas, bahan bagunan/kontruksi, sumber energi, sumber bahan magris/ritual dan lain sebagainya (Lekitoo et al. 2017). Pembangunan di bidang kehutanan diarahkan pada pemanfaatan sumberdaya hutan secara optimal dan lestari serta diupayakan untuk meningkatkan kesejahteraan hidup masyarakat. Pemanfaatan sumberdaya hutan khususnya hasil hutan kayu untuk dijadikan kayu gergajian (Mamusung 2005).
Pendapatan merupakan balas jasa yang diterima seseorang dalam melaksanakan proses produksi (Mamusung 2005). Penggergajian kayu adalah kegiatan mengkonversi kayu maupun panel kayu menjadi produk berdaya guna, bernilai dan berestetika tinggi lewat serangkaian proses (Wahyudi 2013). Pendapatan menjadi faktor penting dalam pengusahaan hutan karena dapat meningkatkan kesejahteraan masyarakat. Karena itu masyarakat yang tinggal di dalam dan sekitar kawasan hutan sering mengumpulkan hasil hutan dan mengelolanya baik untuk memenuhi kebutuhan konsumsi rumah tangga maupun untuk tujuan komersil.

Pengusahaan hutan di Papua tidak terlepas dari hak kepemilikan masyarakat adat. Karena secara de facto (berdasakan fakta) semua hutan di wilayah Papua dikalim sebagai milik komunal atau masyarakat adat, baik hak milik suku maupun marga. Distrik Manokwari Utara merupakan salah satu distrik dari Kabupaten Manokwari, Provinsi Papua Barat yang memiliki potensi hasil hutan yang dimanfaatkan sebagai usaha kayu gergajian oleh masyarakat di sekitar hutan. Karena wilayah ini juga diklaim sebagi milik masyarakat adat Arfak yang menyebut diri mereka sebagai Suku Meyahk.

Tujuan dari penelitian ini antara lain untuk mengetahui pendapatan di tingkat pengusaha kayu (pemilik hak ulayat, 
penampung kayu, dan pengusaha kayu), menilai margin keuntungan di masingmasing pengusaha kayu serta mendeskripsikan alur dan mekanisme/sistem penebangan dan pemanfaatan kayu. Melalui penelitian ini diharapkan memberikan manfaat bagi pemerintah Kabupaten Manokwari dalam menyusun program pengembangan usaha kayu gergajian dan sekaligus sebagai informasi dasar dan studi kelayakan bagi pengusaha kayu gergajian dalam mengambil langkah-langkah penekanan biaya produksi seefisiensi mungkin untuk mendapatkan keuntungan dan diverifikasi, serta pengembangan mutu produk.

\section{METODE PENELITIAN}

Penelitian ini dilaksanakan di Distrik Manokwari Utara Kabupaten Manokwari selama satu bulan yakni dari bulan Juli s/d Agustus tahun 2018. Penelitian ini dirancang menggunakan metode deskriptif dengan teknik survei lapangan. Yang menjadi objek dalam penelitian ini adalah pengusaha kayu gergajian yang mengolah hasil hutan di Distrik Manokwari Utara.

\section{Variabel Pengamatan}

Variabel penelitian ini terdiri dari variabel utama dan variabel penunjang. Variabel utama yang diamati dalam penelitian ini terdiri dari jenis tegakan, besarnya biaya pengusahaan kayu, besar penerimaan pengusahaan kayu serta besarnya pendapatan pengusahaan kayu. Sementara yang menjadi varibel penunjang pada penelitian ini adalah keadaan umum lokasi penelitian.

\section{Prosedur Penelitian}

Secara umum, kegiatan penelitian ini dilakukan melalui beberapa tahapan kegiatan antara lain kegiatan survei awal dimana dilakukan pengecekan lokasi pengambilan data dan mencari informasi mengenai responden yang akan di wawancara. Kemudian dilakukan proses pengambilan data yang terdiri dari

- Pengambilan titik koordinat lokasi penelitian menggunakan global position system (GPS).

- Pengambilan data variabel utama dilakukan dengan wawancara kepada responden menggunakan kuisioner.

- Pengambilan dokumentasi penelitian.

\section{Pengolahan Data}

Data penelitian berupa informasi biaya yang telah dikumpulkan kemudian di entri ke dalam program Microsoft Excel dan diolah menggunakan formula.

\section{Analisis Data}

Data yang diperoleh dianalisis secara deskriptif dan ditampilkan dalam bentuk tabulasi berdasarkan tinggkat pendapatan usaha dari pengusaha kayu gergajian lokal di Distrik Manokwari Utara.

\section{HASIL DAN PEMBAHASAN}

\section{Identitas Pemilik Kayu/Pengusaha Kayu Lokal}

Kawasan hutan yang menjadi lokasi penelitian ini secara hukum merupakan kawasan hutan produksi dan sebagian kawasan lindung, namun berdasarkan kenyataan kawasan hutan ini diklaim sebagai milik beberapa orang sebagai pemilik hak ulayat. Status kepemilikan hak ulayat di wilayah ini dimiliki oleh 
marga Mandacan dan Salabay. Selain sebagai pemilik hak ulayat, responden juga memiliki usaha stand kayu dan penampung kayu. Terdapat satu pemilik stand kayu yang bukan pemilik hak ulayat namun memiliki usaha di wilayah Distrik Manokwari Utara. Indentitas pemilik kayu dan pengusaha kayu lokal di distrik Manokwari Utara disajikan pada tabel 1.

Tabel 1. Identitas pemilik kayu dan pengusaha kayu di Distrik Manokwari Utara

\begin{tabular}{cllcccc} 
No. & \multicolumn{1}{c}{ Responden } & \multicolumn{1}{c}{ Status } & Umur & Pendidikan & $\begin{array}{c}\sum \text { tenaga } \\
\text { kerja }\end{array}$ & $\begin{array}{c}\text { Tahun } \\
\text { berdiri }\end{array}$ \\
\hline 1. & $\begin{array}{l}\text { Bapak wempi } \\
\text { Mandacan }\end{array}$ & $\begin{array}{l}\text { Pemilik hak ulayat dan } \\
\text { Stan Kayu }\end{array}$ & 53 tahun & Sarjana & 5 & 2008 \\
2. & $\begin{array}{l}\text { Ibu Selvi } \\
\text { Sumarenda }\end{array}$ & $\begin{array}{l}\text { Pemilik Stan Kayu } \\
\text { Ibu Vince } \\
\text { Salabay }\end{array}$ & $\begin{array}{l}\text { Pemilik Hak Ulayat dan } \\
\text { Penampung Kayu }\end{array}$ & SMA & 5 & 2008 \\
28 Tahun & SMP & 4 & 2008 \\
\hline
\end{tabular}

Terdapat tiga pengusaha kayu lokal yakni pemilik hak ulayat sekaligus pemilik stand kayu, pemilik hak ulayat sekaligus penampung kayu, dan pemilik stand kayu. Tingkat pendidikan dari ketiga pengusaha kayu mulai dari SMP, SMA dan Sarjana. Pengusaha kayu yang ada di Manokwari Utara memulai usahanya pada tahun 2008, dengan demikian usaha tersebut sudah berjalan selama 10 tahun. Hal ini memberikan gambaran bahwa pengusaha kayu ini mampu bertahan dalam persaingan pasar kayu di Manokwari. Tekanan dari sisi konsumsi kayu di Manokwari saat ini cukup tinggi sehingga menyebabkan produksi dan perolehan kayu bulat semaikin sulit. Usia dari masing-masing pengusaha kayu mulai dari 28 tahun sampai 63 tahun. Usia seseorang akan mempengaruhi produktivitas kerja, karena itu penggunaan tenaga kerja akan sangat membantu pengusah kayu. Jumlah tenaga kerja yang dipekerjakan oleh pengusaha kayu di wilayah Manokwari Utara berkisar dari 4-5 orang. Jenis pekerjaan yang dilakukan adalah sebagai chain saw man (penggergaji kayu), pemikul kayu dan tenaga pemasaran.

\section{Tingkat Pendapatan Pemilik Hak Ulayat/Stand Kayu}

Pendapatan merupakan selisih antara penerimaan dana dan biaya total. Penerimaan dalam penelitian dihitung berdasarkan harga jual kayu di tingkat produsen. Sedangkan pendapatan dihitung untuk masing-masing pemilik hak ulayat sekaligsu stand kayu, pemilik stand kayu sekaligus penampung kayu dan pengusaha stand kayu.

Faktor-faktor yang mempengaruhi tingkat pendapatan adalah biaya, jumlah produksi harga jual dan penerimaan. Secara rinci biaya, penerimaan dan pendapatan dari masing-masing pengusaha kayu di uraikan di bawah ini.

\section{Penerimaan Pemilik Hak Ulayat/Stand kayu Kayu}

Penerimaan adalah jumlah produksi kayu dikalikandengan jumlah kubikasi atau produksi kayu yang dihasilkan dalam satu kali penebangan. Tingkat penerimaan kayu sebagaimana terlihat pada tabel 2 . 
Tabel 2. Penerimaan hak ulayat /stand kayu di Distrik Manokwari Utara

\begin{tabular}{|c|c|c|c|c|c|}
\hline No. & Jenis kayu & $\begin{array}{c}\text { Harga Jual/kubik } \\
\left(\mathrm{Rp} / \mathrm{m}^{3}\right)\end{array}$ & $\begin{array}{c}\text { Kubikasi } \\
\text { /thn }\end{array}$ & $\begin{array}{l}\text { Penerimaan } \\
\text { (Rp/thn) }\end{array}$ & $\begin{array}{c}\text { Persentase } \\
(\%)\end{array}$ \\
\hline 1. & Merbau & 5.000 .000 & 7 & 35.000 .000 & 53,23 \\
\hline 2. & Motoa & 3.000 .000 & 6 & 18.000 .000 & 26,82 \\
\hline 3. & Kayu putih & 2.000 .000 & 7 & 14.000 .000 & 20,89 \\
\hline & Total & 10.000 .000 & 20 & 67.000 .000 & 100 \\
\hline
\end{tabular}

Penerimaan dalam 1 tahun dari pemilik hak ulayat sekaligus pemilik stand kayu adalah Rp 67.000.000, dengan harga jual perjenis Merbau $\mathrm{Rp}$ $5.000 .000 / \mathrm{m} 3$, Matoa Rp 3.000.000/m3 dan kayu Putih Rp 2.000.000/ $\mathrm{m}^{3}$ maka jumlah harga jual sebesar Rp 10.000.000. Bila dilihat dari persentase masingmasing jenis, maka jenis Merbau memberikan kontribusi paling besar yakni 53,23\%. Sedangkan Matoa dan kayu Putih masing-masing sebesar $26 \%$ dan $20 \%$. Hal ini menunjukkan bahwa jenis Merbau masih tersedia di alam dan menjadi minat pasar di wilayah Kota Manokwari dan sekitarnya

\section{Biaya Produksi Kayu Pemilik Hak Ulayat/Stand Kayu}

Biaya produksi dalam penelitian ini terdiri dari biaya bahan bakar, biaya makan, biaya tranportasi, biaya tenaga kerja dan biaya penyusutan alat. Secara keseluruhan jumlah biaya yang dikeluarkan oleh pemilik hak ulayat yang sekaligus sebagai pengusaha kayu adalah sebesar Rp 29.400.000 per tahun seperti pada tabel 3 .

Tabel 3. Biaya produksi kayu pemilik hak ulayat/stan kayu di Distrik Manokwari Utara

\begin{tabular}{lcccc}
\hline \multicolumn{1}{c}{ Jenis biaya } & $\begin{array}{c}\text { Biaya produksi } \\
(\mathrm{Rp})\end{array}$ & $\begin{array}{c}\text { Frekuensi } \\
\text { penebangan/Thn }\end{array}$ & $\begin{array}{c}\sum \text { Tenaga } \\
\text { kerja/bulan }\end{array}$ & $\begin{array}{c}\text { Total biaya } \\
\text { (Rp/tahun) }\end{array}$ \\
\hline Konsumsi/Makan & 500.000 & 7 & & 3.500 .000 \\
BBM & 500.000 & 7 & & 3.500 .000 \\
Transportasi & 200.000 & 7 & & 1.400 .000 \\
Biaya penyusutan & 1.000 .000 & & 4 & 1.000 .000 \\
Tenaga Kerja & 500.000 & 10 & & 20.000 .000 \\
$\quad$ Total biaya & & & & 29.400 .000 \\
\hline
\end{tabular}

\section{Tingkat Pendapatan Pemilik Hak Ulayat/Penampung Kayu}

Tingkat pendapatan dari pemilik hak ulayat yang sekaligus penampung kayu dihitung berdasarkan biaya dan penerimaan dari penjualan kayu. Yang di maksud dengan penampung kayu adalah pemilik hak ulayat yang menyediakan kayu olahan kasar dan kayu menampung sementara sebelum dijual kepada pemilik stand kayu. Dan juga kayu yang sudah siap di jual dalam olahan kasar ke stand kayu namum ada yang sudah bersih yang 
siap dijual kepada konsumen yang ada di Distrik Manokwari Utara dan penampung kayu tidak memiliki ijin resmi dari pemerintah.

\section{Penerimaan Pemilik Hak Ulayat/Penampung Kayu}

Penerimaan adalah jumlah produksi kayu dikali dengan jumlah kubikasi yang dihasilkan dalam satu kali penebangan.
Kontribusi penerimaan kayu terbesar berasal dari kayu Matoa yakni sebesar 57,65\%, disusul kayu Putih 42,35\%. Penerimaan pemilik hak ulayat dan penampung kayu disajikan pada tabel 4 . Penerimaan dari pemilik hak ulayat sekaligus penampung kayu adalah Rp 42.500 .000 dengan harga jual kayu perjenis Rp 3.500.00 dan Rp 3.000.000 jumlah harga jual adalah sebesar Rp 6.500.000.

Tabel 4. Penerimaan pemilik hak ulayat dan penampung kayu

\begin{tabular}{cccccc}
\hline No. & Jenis kayu & Harga jual & Kubikasi/thn & Penerimaan Rp/thn & $\begin{array}{c}\text { Persentase } \\
(\%)\end{array}$ \\
\hline 1. & Matoa & 3.500 .000 & 7 & 24.500 .000 & 57,65 \\
2. & Kayu Putih & 3.000 .000 & 6 & 18.000 .000 & 42,35 \\
& Total & 6.500 .000 & & 42.500 .000 & 100 \\
\hline
\end{tabular}

Penerimaan ini hanya berasal dari kayu Matoa dan kayu Putih sedangkan kayu Meranti tidak tersedia. Hal ini menunjukkan bahwa stok atau ketersediaan kayu Rimba Campuran di wilayah hak ulayat penampung kayu lebih banyak jenis - jenis Rimba Campuran.

Biaya Produksi Kayu Pemilik Hak Ulayat dan Penampung
Biaya produksi dalam penelitian ini terdiri dari biaya bahan bakar, biaya makan, biaya tranportasi, biaya tenaga kerja dan biaya penyusutan alat. Secara keseluruhan jumlah biaya yang dikeluarkan oleh pemilik hak ulayat yang sekaligus sebagai penampung kayu adalah sebesar Rp. 29.400 .000 per tahun seperti pada tabel 5 .

Tabel 5. Biaya produksi kayu pemilik hak ulayat sekaligus penampung kayu di Distrik Manokwari Utara

\begin{tabular}{lcccc}
\hline Jenis biaya & $\begin{array}{c}\text { Biaya produksi } \\
\text { jumlah (Rp) }\end{array}$ & $\begin{array}{c}\text { Frekuensi } \\
\text { penebangan/thn }\end{array}$ & $\begin{array}{c}\text { Tenaga } \\
\text { kerja }\end{array}$ & $\begin{array}{c}\text { Total biaya } \\
(\mathrm{Rp} / \mathrm{thn})\end{array}$ \\
\hline Konsumsi/Makan & 500.000 & 7 & & 3.500 .000 \\
BBM & 500.000 & 7 & & 3.500 .000 \\
Transportasi & 200.000 & 7 & & 1.400 .000 \\
Biaya penyusutan & 1.000 .000 & & 4 & 1.000 .000 \\
Tenaga Kerja & 500.000 & 10 & & 20.000 .000 \\
Total Biaya & & & & \\
\hline
\end{tabular}

\begin{tabular}{lll} 
Pendapatan Pemilik & Hak & Rp. 42.500.000 per tahun. Berdasarkan \\
Ulayat/Penampung Kayu & hasil perhitungan biaya total dan \\
Besarnya biaya total adalah Rp & $\begin{array}{l}\text { penerimaan total tersebut maka } \\
\text { pendapatan total pemilik hak ulayat }\end{array}$ \\
29.400.000, per tahun dan penerimaan & sekaligus pengusaha kayu sebesar Rp. \\
\hline
\end{tabular}


13.100.000,- per tahun. Nilai ini setara dengan pendapata $817.307 /$ minggu. Jadi pendapatan pemilik hak ulayat sekaligus penampung kayu jauh lebih rendah dari hasil penelitian di Kabupaten Jayawijaya (Way 2008). Hal ini wajar karena jenis kayu yang ditampung dan dijual hanya dua jenis.

\section{Tingkat Pendapatan Pengusaha Kayu}

Pengusaha kayu merupakan orang yang memiliki ijin usaha kayu dari pemerintah dalam bentuk surat ijin usaha perdagangan (SIUP) dengan nomor ijin : 341/29-02/PK/20016. Pengusaha kayu umumnya membeli kayu dari penampung kayu dan menjual ke konsumen di Kota Manokwari. Tingkat pendapatan pengusaha kayu dihitung dari biaya-biaya produksi dan penerimaan dari penjualan.

Penerimaan Pengusaha Kayu

Penerimaan adalah jumlah produksi kayu dikali dengan jumlah kubikasi yang dihasilkan dalam satu kali penebangan. Kontribusi penerimaan kayu terbesar berasal dari kayu Merbau yakni sebesar 46,67\%, disusul kayu Matoa 34,65\% dan kayu Putih 18,67\% (Rimba Campuran).

Tabel 6. Penerimaan pengusaha kayu di Distrik Manokwari Utara

\begin{tabular}{llccccc}
\hline No. & Jenis kayu & $\begin{array}{c}\text { Harga jual/kubik } \\
\left(\mathrm{Rp} / \mathrm{m}^{3}\right)\end{array}$ & $\begin{array}{c}\text { Rata-rata jumlah } \\
\text { kayu dijual } \\
\left(\mathrm{m}^{3} / \mathrm{bulan}\right)\end{array}$ & $\begin{array}{c}\text { Rata-rata } \\
\text { Frekuesi } \\
\text { Penjualan }\end{array}$ & $\begin{array}{c}\text { Penerimaan } \\
(\mathrm{Rp})\end{array}$ & Presentasi \\
\hline 1. & Merbau & 5.500 .000 & 1 & 7 & 38.500 .000 & 48,61 \\
2. & Matoa & 4.500 .000 & 1 & 7 & 21.500 .000 & 27,14 \\
3. & Kayu putih & 3.200 .000 & 1 & 6 & 19.200 .000 & 24,24 \\
& Total & 13.200 .000 & & & 79.200 .000 & 100 \\
\hline
\end{tabular}

Penerimaan dari pengusaha kayu atau stan kayu adalah Rp 79.200.000 dengan harga jual kayu per jenis Rp 5.500.00, Rp 4.500.000 dan Rp 3.200.000 jumlah harga jual adalah sebesar Rp 10.200.000. Penerimaan ini hanya berasal dari kayu Merbau, kayu Matoa dan kayu Putih. Hal ini menunjukkan bahwa stok atau ketersediaan kayu Merbau di pengusaha kayu atau stan kayu lebih banyak jenis jenis Rimba Campuran.

Biaya Produksi Pengusaha Kayu

Biaya produksi dalam penelitian ini terdiri dari biaya bahan bakar, biaya makan, biaya tranportasi dan biaya penyusutan alat.

Tabel 7. Biaya produksi pengusaha kayu di Distrik Manokwari Utara

\begin{tabular}{llcl}
\hline Jenis biaya & $\begin{array}{c}\text { Satuan } \\
(\mathrm{Rp})\end{array}$ & $\begin{array}{c}\text { Rata-rata } \\
\text { frekuensi/tahun }\end{array}$ & $\begin{array}{c}\text { Total biaya } \\
(\mathrm{Rp} / \text { tahun })\end{array}$ \\
\hline Rata-rata harga beli kayu & $3.000 .0000 / \mathrm{m} 3$ & 3 & 9.000 .000 \\
Konsumsi/Makan & $500.000 /$ orang & 12 & 6.000 .000 \\
Biaya listrik, dll & 300.000/bulan & 12 & 3.600 .000 \\
Transportasi & 200.000/akut & 6 & 1.200 .000 \\
Biaya penyusutan & $1.000 .000 /$ tahun & & 1.000 .000 \\
Tenaga Kerja 5 orang & $500.000 /$ orang & 12 & 30.000 .000 \\
Total Biaya & & & 50.800 .000 \\
\hline
\end{tabular}


Secara keseluruhan jumlah biaya yang dikeluarkan oleh pemilik hak ulayat yang sekaligus sebagai pengusaha kayu adalah sebesar Rp. 50.800.000 per tahun seperti pada tabel 7.

\section{Pendapatan Pengusaha Kayu di Distrik Manokwari Utara}

Besarnya biaya total adalah $\mathrm{Rp}$ 50.800.000, per tahun dan penerimaan Rp. 79.200.000 per tahun. Berdasarkan hasil perhitungan biaya total dan penerimaan total tersebut maka pendapatan total pemilik hak ulayat sekaligus pengusaha kayu sebesar Rp. 28.400.000,- per tahun. Nilai ini setara dengan pendapatan Rp. 546,153/ minggu. Jadi pendapatan pemilik hak ulayat sekaligus penampung kayu jauh lebih rendah dari hasil penelitian di Kabupaten Jayawijaya (Way 2008). Hal ini wajar karena jenis kayu yang ditampung dan dijual hanya dua jenis.

\section{Margin Keuntungan}

Marjin keuntungan adalah indikator yang utama tentang keberhasilan perusahaan secara keseluruhan dan biasanya dinyatakan dalam bentuk persentase. Rasio marjin keuntungan digunakan untuk menggambarkan kemampuan perusahaan untuk menghasilkan laba dan mempertimbangkan beberapa skenario seperti peningkatan biaya yang dianggap tidak efektif, dan digunakan secara ekstensif dalam pemodelan keuangan dan penilaian perusahaan. Marjin keuntungan yang tinggi berarti bahwa suatu perusahaan dapat secara efektif mengendalikan biaya dan/atau menyediakan barang atau jasa dengan harga yang jauh lebih tinggi dari biayanya. Oleh karena itu, rasio yang tinggi dapat dihasilkan dari : manajemen yang efisien, biaya yang rendah (pengeluaran), strategi penetapan harga yang kuat. Margin keuntungan dalam penelitian ini dihitung untuk setiap pelaku usaha yaitu pemilik hak ulayat dan pengusaha kayu, pemilik hak ulayat sekaligus penampung kayu, dan pengusaha kayu.

\section{Marjin Keuntungan Pemilik Hak ulayat sekaligus Pengusaha Kayu}

Margin keuntungan dari pemilik hak ulayat sekaligus pengusaha kayu dari ketiga jenis kayu komersil yaitu Merbau (Intsia bijuga), Matoa (Pometia spp.) dan kelompok kayu Rimba Campuran adalah sebesar 56,11\%. Pada pelaku usaha ini (pemilik hak ulayat sekaligus pengusaha kayu) penerimaan (keuntungan) dari hasil penjualan kayu pada stand kayu sebesar Rp. 67.000.000 per tahun. Sedangkan jumlah pendapatan yang diterima adalah sebesar 29.400.000, per tahun. Secara ekonomis marjin keuntungan dihitung seperti di bawah ini :

\section{Marjin Keuntungan $=$ $29.400 .000 / 67.000 .000 \times 100 \%=56,11 \%$.}

Margin keuntungan pada pengusaha kayu tersebut memiiki nilai yang tinggi yaitu $56,11 \%$. Hal ini disebabkan tidak terdapatnya biaya pembelian kayu karena kayu dipanen dari hutan yang menjadi hak milik adat. Artinya bahwa pengusaha kayu menggunakan struktur biaya yang tidak efektif. Selain itu, pengusaha kayu ini juga memiliki relasi dengan konsumen sehingga pasar tersedia selalu.

\section{Margin Keutungan Pemilik Hak Ulayat/Penampung Kayu}

Hasil penelitian ini menunjukkan bahwa margin keuntungan dari pemilik hak ulayat sekaligus penampung kayu 
dari satu jenis kayu komersila yaitu Matoa (Pometia spp.) dan kelompok kayu Rimba Campuran adalah sebesar 30,82\%. Pada pelaku usaha ini (pemilik hak ulayat sekaligus penampung kayu) mendapat penerimaan (keuntungan) dari hasil penjualan kayu sebesar Rp. 42.500.000 per tahun. Sedangkan jumlah pendapatan yang diterima adalah sebesar $\mathrm{Rp}$ 13.100.000 per tahun. Secara ekonomis margin keuntungan dihitung seperti di bawah ini.

\section{Margin keuntungan $=$ \\ $13.100 .000 / 42.500 .000 \times 100 \%=30,82 \%$}

Margin keuntungan pengusaha kayu memiliki nilai yang cukup baik yakni dibawah 60\%. Hal ini disebabkan pengusaha kayu ini menjual kayu yang berasal dari hak ulayat sehingga tidak ada biaya pembeliaan kayu dan pengusaha kayu menjual langsung kepada konsumen. Artinya pengusaha ini menggunakan struktur biaya yang efektif. Meskipun demikian strategi penjualan yang dilakukan dan manajemen yang dijalankan belum efisien.

\section{Margin Keutungan Pengusaha Kayu}

Pengusaha kayu memiliki margin keuntungan dari ketiga jenis kayu komersil yaitu Merbau (Intsia bijuga), Matoa (Pometia spp.) dan kelompok kayu Rimba Campuran sebesar 35,85\%. Pelaku usaha ini (pengusaha kayu) mendapat penerimaan (keuntungan) dari hasil penjualan kayu pada stand kayu sebesar Rp. 79.200.000 per tahun. Sedangkan jumlah pendapatan yang diterima adalah sebesar Rp 28.400.000 per tahun. Secara ekonomis margin keuntungan dihitung seperti di bawah ini :

\section{Margin Keuntungan $=$ \\ $28.400 .000 / 79.200 .000 \times 100 \%=35,85 \%$}

Margin pengusaha kayu masih berada diatas $30 \%$ yang artinya bahwa pengusahaan menggunakan struktur biaya yang efektif, strategi penetapan harga yang cukup baik. Oleh karena itu, rasio tinggi dapat dihasilkan. Hal ini terlihat dari selisih harga beli dan harga jual sebesar Rp. 4.500 .000 per jenis kayu.

\section{Perbandingan Margin Keuntungan antara Pengusaha Kayu}

Margin keuntungan pada setiap pengusaha kayu memilik nilai yang berbeda dengan kisaran $35-86 \%$, seperti terlihat pada tabel 8 .

Tabel 8. Perbandingan margin keutungan pengusaha kayu di Distrik Maokwari Utara

\begin{tabular}{lc}
\multicolumn{1}{c}{ Pengusaha kayu } & $\begin{array}{c}\text { Margin keuntungan } \\
(\%)\end{array}$ \\
\hline Pemilik hak ulayat/stand kayu & 56,11 \\
Pemilik hak ulayat/penampung & 30,82 \\
Pengusaha kayu & 35,85 \\
\hline
\end{tabular}

Perbandingan margin keuntungan dari ketiga pengusaha terlihat bahwa pemilik hak ulayat sekaligus pemilik stand kayu memiliki margin keuntungan tinggi (56\%). Sedangkan antara pemilik hak ulayat sekaligus penampung kayu dan pengusaha kayu terdapat selisih hanya sekitar 30\%. Kondisi ini menunjukkan bahwa margin keuntungan untuk tiap pengusaha kayu sangat dipengaruhi oleh faktor efisiensi biaya. Karena pemilik hak ulayat tidak mengeluarkan biaya 
pembelian kayu sedangkan pengusaha kayu harus menyediakan biaya pembeliaan kayu. Artinya pengusaha kayu belum efisen dalam mengelola biaya dan memiliki kelemahan dalam strategi penetapan harga. Selain faktor biaya, strategi penetapan harga dan manajemen usaha juga menjadi kunci terhadap naik turunya margin keuntungan.

\section{Alur Perdagangan Kayu Pengusaha Kayu Lokal}

Kayu-kayu yang dijual oleh ketiga pengusaha kayu berasal dari hutan yang dimiliki oleh pemilik hak ulayat suku Meyakh. Proses pengusahaan kayu diawali dengan penunjukkan areal hutan yang memiliki potensi kayu oleh pemilik hak ulayat. Selanjutnya kegiatan penebangan dilakukan oleh karyawan dari masing-masing pemilik hak ulayat dengan tenaga kerja antara 4-5 orang. Setelah kayu ditebang selanjutnya dipikul ke lokasi penampungan sementara dipinggir jalan untuk selanjutnya diangkut ke tempat penampungan maupun stand kayu. Setiap pengusaha kayu memiliki strategi penjualan dan konsumen yang berbeda sehingga penjualan dapat dilakukan langsung ke stand kayu dan juga ke konsumen akhir maupun ke pemilik stand kayu. Bila penjualan dilakukan ke konsumen akhir margin keuntungannya tinggi (56\%). Sedangkan kalau dijual ke stand kayu margin keuntungannya hanya 35,85\%.

Penampung kayu hanya menjual kayu kepada pengusaha kayu (pemilik stand kayu) dan ke konsumen akhir yang berada di Distrik Manokwari Utara. Dengan demikian harga jual kayunya lebih kecil. Sementara pengusaha kayu menjual kayu selain di Distrk Manokwari Utara juga dijual ke konsumen di kota Manokwari dan sekitarya.

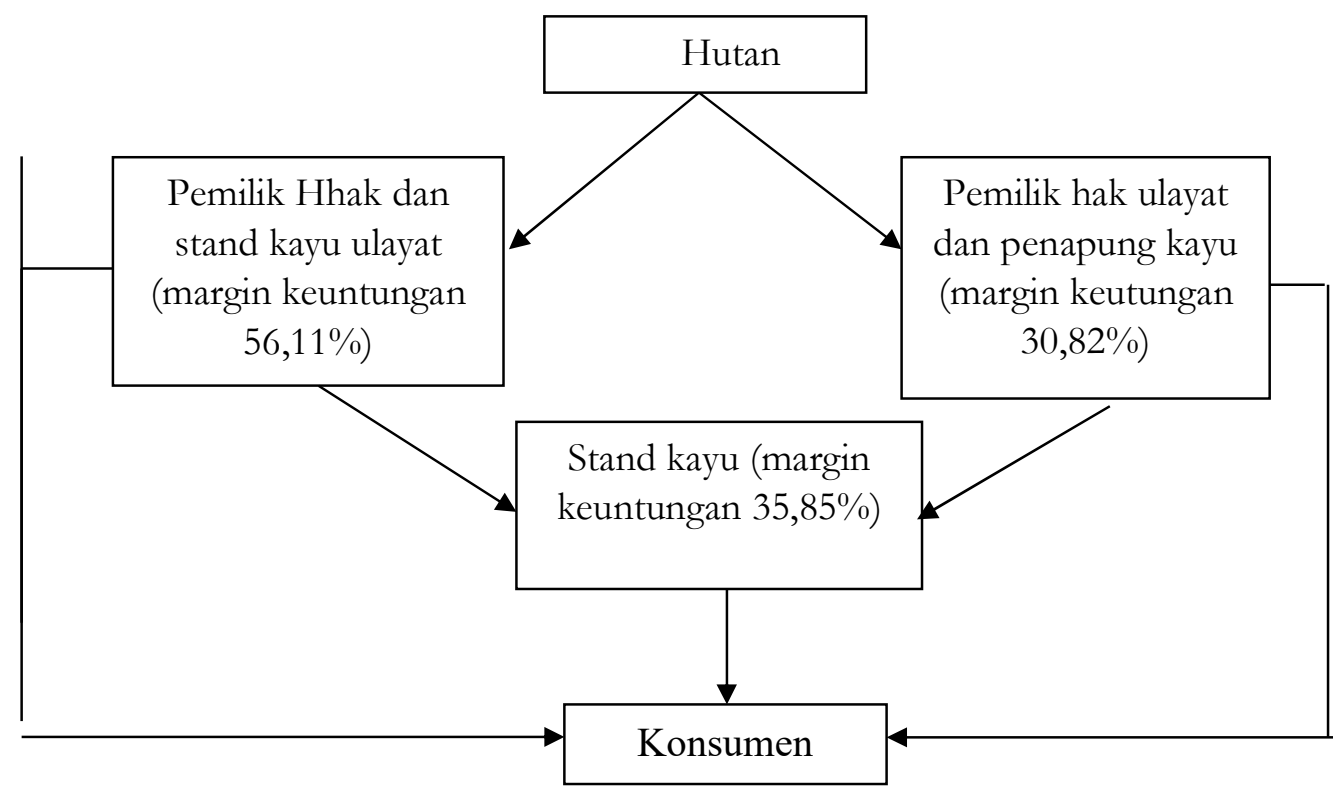

Gambar 1. Alur perdangan kayu dan margin keuntungan di masing-masing pengusaha kayu 
Ketiga pengusaha kayu membangun hubungan perdagangan yang menguntungkan dengan pasar dimulai dengan memahami kebutuhkan dan keinginan konsumen, memutuskan tujuan pemasaran yang dapat dilayani dengan mendatangi konsumen sasaran atau melalui informasi orang lain. Bila hal ini dilakukan dengan baik, maka pengusaha kayu lokal ini akan meraih pangsa pasar, keuntungan, dan ekuitas pelanggan yang baik (Khotler dan Armstrong 2009). Secara hukum kegiatan penebangan kayu yang dilakukan dalam wilayah hak ulayat ada ijin resmi dari dinas atau instansi terkait. Pengangkutan kayu dilakukan dengan faktur angkutan kayu olahan.

\section{DAFTAR PUSTAKA}

Kotler P dan Armstrong G. 2008. Prinsipprinsip pemasaran. Edisi 12. Jilid 1. Jakarta: Erlangga.

Lekitoo K, Peday HFZ, Panambe N and Cabuy RL. 2017. Ecological and ethnobotanical facet of 'Kelapa Hutan' (Pandanus spp.) and perspectives towards its existence and benefit.
International Journal of Botany, 13: 103-114.

Mamungsu EY. 2005. Analisis penapatan pada industri mebel rotan di Kota Sorong. [Skripsi]: Fakultas Kehutanan Universitas Papua Manokwari. (Tidak diterbitkan).

The World Bank. 2008. Penilaian strategis untuk perencanaan puang di Provinsi Papua. The World Bank bekerjasa dengan Pemerintah Provinsi Papua.

http://documents.worldbank.org/curate d/en/166831468038710102/pdf/47678 0WP0BAHAS10Box338858B01PUB LIC1.pdf.

Wahyudi. 2013. Dasar-dasar penggergajian kayu. Yogyakarta: Pohon Cahaya.

Way J. 2008. Analisis pendapatan usaha kayu lokal masyarakat di Kabupaten Jayawijaya. Akses online: Maret 02 2020.

http://pasca.unhas.ac.id/jurnal/files/28 d082fa5ece12092d9ca10bd2a23858.pd f. 